\title{
TANGERANG CITY GOVERNMENT POLICY TO DEVELOP CHILD FRIENDLY CITY
}

\author{
Andriansyah ANDRIANSYAH ${ }^{1}$, Taufiqurokhman TAUFIQUROKHMAN², \\ Ma'mun MURAD ${ }^{3}$, and Veny Agustini PRIANGGITA ${ }^{4}$ \\ 1,2 Universitas Prof.Dr. Moesopo (Beragama) \\ ${ }^{3}$ Universitas Muhammadiyah Jakarta \\ ${ }^{4}$ Universitas Mathla'ul Anwar \\ andriansyah@dsn.moestopo.ac.id ${ }^{1}$, taufiqurokhman@dsn.moestopo.ac.id²,mamun.murod@umj.ac.id², veny. \\ agustini@unmabanten.ac.id ${ }^{4}$
}

\begin{abstract}
Community service research aims to find out the Policy Development of the City Government (Pemkot) of South Tangerang (Tangsel) in implementing Women's Empowerment and Child Protection of the Republic of Indonesia in accordance with Ministerial Regulation Number 11 of 2011, concerning Child Friendly City Development Policies (KLA) in South Tangerang City Government Banten Province. Using a descriptive qualitative approach research method. That is to explain the phenomenon in depth through data collection. This type of research provides an overview, objectively precise explanation of the actual state of the object under study. Research design in research writing uses the theory of public policy making according to Metter and Horn. The results of the research on the development of South Africa's KLA generally went well. Among them; the achievement of basic health and welfare, the large number of breastfeeding facilities and the ASI corner, the high percentage of complete basic immunization for children, the low prevalence of malnutrition in children under five, the low infant mortality rate (IMR), and the active and successful PIKKRR (Adolescent Reproductive Health Counseling Information Center) .
\end{abstract}

Key Word: Policy, Child Friendly City Development, South Tangerang

\section{BACKGROUND}

A child is a person who is not yet 18 (eighteen) years old, including those who are still in the womb (Regulation of the State Minister for Women's Empowerment and Child Protection Number 11 of 2011, concerning Child Friendly City Development Policy (Eligible City of Children). Developed to be able to participate actively in development, therefore, it is important to foster the child's mentality and morality out of the Ministry of Women's Empowerment and Child Protection No. 11 of 2011, concerning the Child Friendly City Development Policy, which has been categorized as Eligible City Of Children has a development system based on children's rights through a comprehensive and sustainable integration of commitment and resources of government, society and business world in policies, programs and activities to ensure the fulfillment of children's rights, meaning that there are three elements involved, namely: Government, community and business. To facilitate the classification of the fulfillment of children's rights, the grouping of indicators is divided into six parts, which include the institutional strengthening section and 5 (five) children's rights clusters, namely: (1) Civil rights and freedom; (2) Family environment and alternative care; (3) Basic health and welfare; (4) Education, utilization of leisure time and cultural activities; (5) Special Protection.

Banten Regional Government Province of Indonesia is one of the Republic of Indonesia's Republic of Indonesia buffer regions which has a lot of potential for development. Development in various sectors must be balanced with the fulfillment of children's rights. Therefore, the quality of children is a determinant of the sustainability and success of development in the future. Of the eight districts / cities in the Banten Regional Government, only South Tangerang
City has received the Eligible City of Children award from the Ministry of Women's Empowerment and Child Protection. South Tangerang City is one of 37 districts and cities that received the Eligible City of Children award in the pratama category.

As a form of institutional strengthening in the implementation of the Eligible City of Children Development Policy in South Tangerang, South Tangerang Mayor Decree Number 463 /Kep-185-Huk / 2011 was made concerning the Child Friendly City Task Force of South Tangerang City. There is also the Regional Regulation of South Tangerang City Number 3 of 2012, concerning Protection of Women and Children Victims of Violence. This proves the seriousness of the South Tangerang City Government in making regulations that regulate the guarantee of children's rights. In addition, some of the fulfillment of children's rights in South Tangerang City have also been good. One of them is the fulfillment of children's rights for educational clusters, the use of leisure time and cultural activities, namely the high rate of participation in early childhood education in the City of South Tangerang City, judging by the number of preschool institutions in South Tangerang City. This which later became an added value in the assessment of South Tangerang City won the first level of Child Friendly Regency / City (Eligible City of Children) award.

Even so, the implementation of the Eligible City of Children development policy in South Tangerang City does not just run smoothly, there are problems including the number of children whose civil rights have not been fulfilled, namely many who do not have a birth certificate, lack of government attention to some facilities and infrastructure development towards the Eligible City of Children, can be seen from the lack of quantity and 
quality of the Happy School Zone. In fact, the existence of Happy School Zone is considered to be very effective in preventing accidents, especially for students who are still in elementary school, the Regional Government of South Tangerang City does not have a shelter for rehabilitation for street children. Thus, street children who are netted are only recorded, without any rehabilitation efforts. So that the Regional Government of South Tangerang City has not been able to alleviate street children problems completely. Of the approximately 50 institutions in South Tangerang City including the Childcare Social Institution, all are managed by the private sector. Lack of active role of the Child Protection Task Force (PA Task Force) at the citizens Association level in conducting socialization and counseling in preventing cases of domestic violence (domestic violence) including violence against children. In accordance with article 4 of Law No.23 of 2002 concerning Child Protection, that every child has the right to be able to live, grow, develop and participate naturally in accordance with human dignity and dignity, and to be protected from violence and discrimination. Lack of coordination between Child Friendly City Task Force in South Tangerang City. In addition, a lack of coordination was also seen from several Regional Work Unit who did not understand well the main tasks and functions in the Eligible City of Children Task Force. In addition, so many parties involved, both from the government, community, and the world in the Eligible City of Children Task Force make coordination tend to be difficult to do optimally.

\section{METHODE}

In this study, the authors use a qualitative approach that is descriptive, which explains the phenomenon in depth through data collection. This type of research provides an overview, an accurate explanation objectively about the actual state of the object under study. In this study to determine the informants that can be explored accurate information using purposive sampling technique that is by selecting resource persons who really know the internal and external conditions of the South Tangerang City Government Office. So that it will provide proper input on the implementation of the Regulation of the Minister of Women's Empowerment and Child Protection of the Republic of Indonesia Number 11 of 2011 concerning the Development Policy of Decent Districts / Cities in Eligible City of Children in South Tangerang City. The informants selected from this study came from Tangerang City Government Office employees and this study also used accidental sampling technique which was taken from the people who participated in the Policy Implementation of Decent City of South Tangerang Children.

Informants are people who really know or are actors who are directly involved with research problems. This informant must have a lot of experience about research, and can provide views on the values, attitudes, processes and culture that are the background of local research. Data
Analysis Techniques uses a theoretical approach from Miles and Huberman (1992: 20), qualitative data analysis consists of: (1) Data reduction is defined as the process of selecting, formulating, paying attention to simplification, abstracting and rough data information arising from written records in the field. Date reduction is a form of analysis to sharpen, classify, direct, dispose of unnecessary and organize data in such a way that conclusions can finally be drawn and verified; (2) Presentation of data on a set of information that has been arranged in an integrated and understood manner that gives the possibility of drawing conclusions and taking action; (3) Draw conclusions on verification of various data findings obtained during the research process.

\section{RESULT AND DISCUSSION \\ Profile of South Tangerang City}

Research Location Profile: South Tangerang City is a city located in Tatar Pasundan Banten Province, Indonesia. The city is located $30 \mathrm{~km}$ west of Jakarta and $90 \mathrm{~km}$ southeast of Serang, the capital of Banten Province. Tangerang Selatan consists of 7 sub-districts, which are further divided into 54 kelurahan and 5 villages. Based on Law Number 51 of 2008, South Tangerang consists of 7 (seven) districts: (1) Serpong with an area of 2,404 Ha; (2) North Serpong with an area of 1,784 Ha; (3) Ciputat with an area of 1,838 Ha; (4) East Ciputat with an area of 1,543 Ha; (5) Pondok Aren with an area of 2,988 Ha; (6) Pamulang with an area of 2,682 Ha; (7) Setu with an area of $1,480 \mathrm{Ha}$.

The South Tangerang City Government borders the City of Tangerang in the north, Bogor Regency (West Java Province) in the south, Tangerang Regency in the west, and the Jakarta Special Capital Region in the east. In terms of population, South Tangerang is the second largest city in Banten Province after the City of Tangerang and the fifth largest in the Greater Jakarta area after Jakarta, Bekasi, Tangerang and Depok. The area of South Tangerang City is the result of the expansion of the Tangerang Regency.

South Tangerang is located in the eastern part of Banten Province, which is at coordinate points 106'38 '106'47' East Longitude and 06'13'30 ‘- 06'22’30' South Latitude. The area of Tangerang Selatan City is crossed by Kali Angke, Kali Pesanggrahan and Cisadane River as the administrative boundaries of the city to the west. The geographical location of South Tangerang, which borders DKI Jakarta Province on the north and east, provides an opportunity for South Tangerang City as one of the buffer zones of DKI Jakarta province, in addition to being an area that connects Banten Province with DKI Jakarta. In addition, South Tangerang is also one of the regions that connects Banten Province with West Java Province.

Furthermore, the author will explain the Pure Participation Rate (APM) and the Gross Enrollment Rate (APK) according to the level of education in South 
Tangerang City which will later relate to Tangerang City which has become a Decent City for children where one of them is based on the APM and APK that the child can school. More specifically, the APM and APK figures will be explained in Table 1 about the APM and APK below:

Table 1. Pure Participation Rate (APM) and Gross Participation Rate (APK) According to Education Level in South Tangerang City

\begin{tabular}{|lcccc|}
\hline \multirow{2}{*}{ Educational level } & \multicolumn{2}{c}{ APM } & \multicolumn{2}{c|}{ APK } \\
\cline { 2 - 5 } & $\mathbf{2 0 1 5}$ & $\mathbf{2 0 1 4}$ & $\mathbf{2 0 1 5}$ & $\mathbf{2 0 1 4}$ \\
\hline SD & 98.88 & 98.33 & 113.11 & 108.36 \\
MI & 84.81 & 76.48 & 87.88 & 86.65 \\
SMP & 79.61 & 63.39 & 94.24 & 71.38 \\
\hline
\end{tabular}

Source: BPS Data for South Tangerang City, 2016

From the table above shows that NER and GER are seen from Primary Schools (SD), Madrasah Iftidyah (MI) to Junior High Schools (SMP) have increased. For the 2014 primary school APM was 98.33 and in 2015 it was 98.88. Next can be seen in the table above. Whereas for the data the number of residents of Tangerang City, based on data from the Central Statistics Agency, will be mentioned below this table 2 .

The establishment of an autonomous city of South Tangerang or formerly called Cisera which is included in Banten Province, Indonesia emerged since 1999. But the absence of an agreement between the DPRD and the Tangerang Regency Government regarding the number of sub-districts that will be incorporated in this autonomous city, hampers the formation process. Most of the people living in Ciputat, Pamulang, Serpong, Cisauk, and Pondok Aren sub-districts want to escape from Tangerang Regency. Another consideration is the aspect of community service and the Regional Original Revenue (Regional Original Income) of the six subdistricts is very large, namely 309 billion per year or $60 \%$ of the Regional Original Income in all Tangerang Regency.

Table 2. Number of Population in South Tangerang City 2010 - 2016

\begin{tabular}{|c|c|c|c|c|c|c|c|}
\hline \multirow{2}{*}{ districts } & \multicolumn{7}{|c|}{ Number of Population (Soul) } \\
\hline & 2010 & 2011 & 2012 & 2013 & 2014 & 2015 & 2016 \\
\hline Setu & 66667 & 69391 & 72170 & 75002 & 77881 & 80811 & 83777 \\
\hline Serpong & 138177 & 144378 & 150736 & 157252 & 163915 & 170731 & 177677 \\
\hline Pamulang & 287955 & 296915 & 305909 & 314931 & 323957 & 332984 & 341967 \\
\hline Ciputat & 193369 & 199807 & 206293 & 212824 & 219384 & 225974 & 232559 \\
\hline Ciputat Timur & 179792 & 184391 & 188957 & 193484 & 197960 & 202386 & 206729 \\
\hline Pondok Aren & 305073 & 316988 & 329103 & 341416 & 353904 & 366568 & 379354 \\
\hline Serpong Utara & 127471 & 134232 & 141237 & 148494 & 155998 & 163755 & 171749 \\
\hline $\begin{array}{l}\text { South } \\
\text { Tangerang City }\end{array}$ & 1298504 & 1346102 & 1394405 & 1443403 & 1492999 & 1543209 & 1593812 \\
\hline
\end{tabular}

Source: BPS Data for South Tangerang City, 2016

Community Empowerment In Tourism \& Creative Economy
Finally, on September 29, 2008 Act No. 51 of 2008 concerning the Establishment of the City of South Tangerang through the House of Representative of Indonesia Republic Plenary Session, with the district coverage area. Setu, Serpong, Serpong Utara, Pondok Aren, Pamulang, Ciputat, and Ciputat Timur join in an autonomous city called South Tangerang City. The border area of South Tangerang City is to the north, namely the border between Tangerang City and the Special Capital Region of Jakarta. In the south is the border of West Java Province, namely Bogor Regency and Depok City. In the west, Tangerang Regency and the East borders the West Java Province, namely the City of Depok and the Special Capital Region of Jakarta. For further information, the writer will explain about the literature review or literature in the discussion on the Development of South Tangerang City Regional Government Policy viewed from the concept of public policy review below.

\section{Public Policy Development}

In this paper the author will describe the concept of public policy development from his theory Marlowe in Wicaksono (2006: 56): "Policy is an attempt to create or engineer a story in order to secure the goals of the engineer. "The term policy contains the same meaning as the notion of wisdom, as expressed by an expert James in Wahab (2005: 2), who formulates:" Wisdom as a behavior of a number of actors (officials, groups, government agencies) or a series of actors in a field certain activities. "

Friedrich in Winarno (2012: 20) views policy as: "A direction of action proposed by a person, group, or government in a particular environment that provides obstacles and opportunities to the proposed policy to use and overcome in order to achieve a goal or realize a goal or a specific purpose ". The definition concerns a broad dimension because policy is not only understood as an action taken by the government, but also groups and individuals. Jones in Winarno (2012: 19): "The term policy (policy term) is used in daily practice but is used to replace very different activities or decisions. This term 
is often exchanged for goals (goals), programs, decisions (decisions), standards, proposals, and grand design. “ Marlowe in Wicaksono (2006: 56): "Policy is an attempt to create or engineer a story in order to secure the goals of the engineer. "The term policy contains the same meaning as the notion of wisdom, as expressed by an expert James in Wahab (2005: 2), who formulates:" Wisdom as a behavior of a number of actors (officials, groups, government agencies) or a series of actors in a field certain activities. "

Public policy is one of the most important studies in the State Administration Study Program, because it is needed to make a draft law or policy in running a government. Various problems in government in the framework of development can be solved through a public policy. Nugroho in his book entitled Public Policy: Formulation, Implementation and Evaluation (2003: 54), said that things that were decided by the government were not to be done or left unchecked. For this reason, Public Policy does not always have to be in the form of legislation, but can be in the form of unwritten rules but agreed upon. In simple terms, it can be said by Nugroho in his book Public Policy (2011: 96) that public policy is "every decision made by the state, as a strategy to realize the goals of the country. Public policy is a strategy to usher in the early community, to enter the community during the transition period, to go to a society that is aspired. "Public policy taken by private organizations and government institutions must represent the voices of the public itself, even though in reality so many desires must be carried out. For this reason, several steps must be taken before taking a policy and Nugroho (2003: 73), said that there are 3 stages of Public Policy, namely: (1) Policy Formulation; (2) Policy Implementation; (3) Policy Evaluation.

Policy development usually in policy theory is an implementation step or commonly referred to as implementation of a program involving policy maker efforts to influence the behavior of executing bureaucrats to be willing to provide services and regulate the behavior of the target group (Subarsono, 2010: 87). According to Metter and Horn in Wahab (2005: 65) formulates the implementation process as: "Actions taken by individuals or officials or groups of government or private sector directed at achieving the goals outlined in the decision wisdom.

Development of public policy according to Nugroho in Public Policy (2011: 618) that the implementation of policies in principle is a way for a policy to achieve its objectives. Meanwhile, Abidin (2012: 163) explained that: "The implementation of a policy is basically a multiorganizational transformation. Therefore, the implementation strategy relates the interests that are accommodated, the more likely a policy is successfully implemented. "The following will be discussed further about the various variables involved in policy implementation through the following theories:

Model Policy Development George C. Edward III. Edward III in Agustino (2008: 149) called the implementation of public policy with Direct and Indirect Impact on Implementation. In the approach applied by Edward III, there are four variables that determine the success of a policy, namely: (1) Communication. There are three indicators that can be used (or used) in measuring the success of the communication variables mentioned above, namely: (a) Transmission; (b) Clarity; (c) Consistency. Whereas the second or (2) are Resources. Where consists of several elements, namely: (a) Staff; (b) Information; (c) Authority; (d) Facilities. The third is Disposition, namely the important things that need to be observed in the variable disposition, according to George C. Edward III, are: (a) Appointment of Bureaucrats; (b) Incentives. And the fourth is the bureaucratic structure. Two characteristics, according to Edward III, which can boost the performance of a better bureaucracy / organization structure towards: (a) Conduct Standard Operating Procedures (SOPs); (b) Carry out Fragmentation.

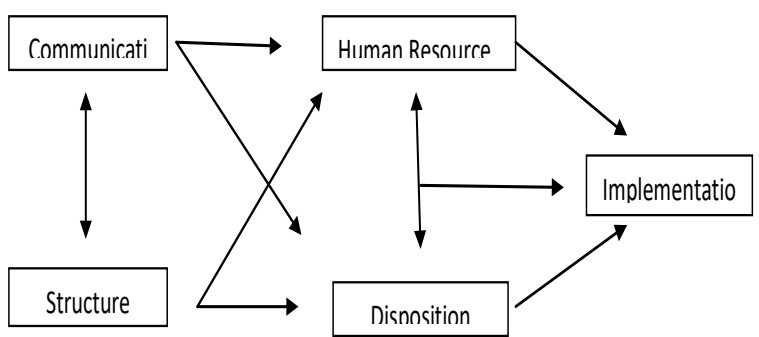

figure 1. Model 2.4. Direct and Indirect Approach on Implementation by Edward III

Based on the explanation above, it can be concluded that the implementation of a policy is strongly influenced by the existence of good and clear communication between individuals and related institutions, both those who are executors and policy targets; fulfillment of needed resources; good implement or attitude or behavior; and a dynamic and flexible bureaucratic structure in the sense that it is not rigid or convoluted.

\section{Model Policy Development Donald S. Van Metter and Carl Van Horn.}

Agustino in the Basics of Public Policy (2008: 141) explained that the approach model formulated by Metter and Horn is called A Model of the Policy Implementation. This implementation process is an abstraction or performance of a policy implementation which is basically intentionally carried out to achieve high public policy implementation performance that takes place in a variable relationship. This model assumes that policy implementation runs linearly from available political decisions, implementers, and public policy performance. There are six variables according to Metter and Horn, which affect the performance of public policies as follows (Agustino, 2008: 142).

\section{Understanding The Decent City of Children}

The results and discussion in writing researchers use public policy development theory according to Metter 
and Horn. Because there is a match between the problems contained in the identification of problems with what is described in the theory. There are six variables according to Metter and Horn, which affect the performance of public policies as follows (Agustino, 2008: 142), namely: (1) Size and Purpose of Policy; (2) Resources; (3) Characteristics of Implementing Agents; (4) Attitudes and trends; (5) Inter-Organizational Communication and Implementing Activities; (6) Economic, Social and Political Environments.

First, Policy Size and Purpose. The South Tangerang City Government began launching the Eligible City of Children Development Policy since 2011 through strengthening political commitment shown by forming the Eligible City of Children Task Force. The purpose of the Eligible City of Children Development Policy in South Tangerang City is in accordance with what is stated in the Minister of Women's Empowerment and Child Protection Regulation No. 11 of 2011 concerning Development Policies for Decent Cities / Children, to build district / city government initiatives that lead to efforts to transform the Convention on the Rights of the Child from the legal framework into definitions, strategies and development interventions, in the form of: development policies, programs and activities aimed at the fulfillment of children's rights, in a district / city area.

Second, resources consist of human resources, financial resources, and time resources. Human resources in the implementation of Eligible City of Children development policies in South Tangerang City are sufficient in quality and quantity. Financial resources come from the Regional Expenditure Budget, which is sufficient for the implementation of the Eligible City of Children development policy, but it is still considered limited or has not fully met the needs for socialization activities and also for the development of children's rights cluster facilities and infrastructure. And for time resources, the South Tangerang City Government's own policy does not have a clear time target because the policy must be sustainable.

Third, the characteristics of implementing agents in the Eligible City of Children Development Policy must be synchronized with each other, all aspects must be involved. In addition to coordination, which is an obstacle, the weak socialization of the sub district or kelurahan activities. In addition, the Eligible City of Children Task Force strengthening is also felt to be less than optimal because Regional Work Unit initiatives are still lacking. The implementing agency for Eligible City of Children Development Policy in South Tangerang City has not been maximized.

Fourth, the attitude / disposition of the implementers. The response or response of the implementing agency of the Eligible City of Children Development Policy in South Tangerang City is generally good and mutually supportive. However, the implementation of the policy for some implementing agencies is also expected not to pursue mere appraisal or appreciation. The Eligible City of Children Policy Implementation in South Tangerang City will be difficult to materialize if all implementing agencies do not have the same view of the importance of fulfilling children's rights in the regional development system.

Fifth, communication between organizations and implementing activities. The Eligible City of Children Development Policy is a policy of the central government that is carried out by the district / city Regional Government involving all elements, starting from the local government, the business world, and the community, therefore coordination plays a very important role. Because coordination is needed so that the Eligible City of Children Development Policy can run and not overlap the duties of each stakeholder so that the main tasks and functions of each party concerned must understand.

\section{Understanding The Decent City of Children (Eligible City of Children)}

Understanding of Decent Districts / Cities (Eligible City of Children) are: District/city development system that integrates a planned and comprehensive commitment and resources of the government, community and business world in policies, programs, and activities for the fulfillment of children's rights. The importance of realizing Regional Work Unit is as follows:

a. The number of children is about one third of the total population.

b. Children are capital and investment in human resources in the future, as well as the next generation of the nation.

c. Children must be quality so as not to become a development burden.

d. Coordination and partnerships between stakeholders related to the fulfillment of children's rights must be strengthened to be integrated, holistic and sustainable.

\section{Eligible City of Children Purpose}

The Eligible City of Children aims to build district / city government initiatives that lead to efforts to transform the Convention on the Rights of the Child from the legal framework into definitions, strategies and development interventions, in the form of: development policies, programs and activities that intended for the fulfillment of children's rights, in a district / city area.

\section{Principles, Strategies and Scope of Eligible City of Children}

The Eligible City of Children principles are as follows: (1) Nondiscrimination; (2) The best interests for children; (3) The right to live, grow and develop; (4) Appreciation for children's opinions. Eligible City of Children adopts a strategy of prioritizing children's rights, which means integrating children's rights into: (1) Every drafting process: Policies, programs and activities; (2) Every stage of development: planning and budgeting, implementation, monitoring and evaluation; (3) Every level of territory: 
national, provincial and district / city, sub-district to village or kelurahan. The scope of Eligible City of Children covers all fields of development, which are grouped into: (1) Child Development; (2) Child Protection.

\section{CONCLUSIONS AND RECOMMENDATIONS Conclusions}

The development of the District / City Development Policy (Regional Work Unit) in the City of South Tangerang has generally been going well, judging by the achievement of these policy objectives with the fulfillment of most of the rights of the child based on the Convention on the Rights of the Child (CRC), although there are a number of things that still need improvement. The best fulfillment of children's rights clusters in the implementation of the District or City Development Policy (Regional Work Unit) in South Tangerang City based on the Convention on the Rights of the Child (CRC) is basic health and welfare, as seen from the large number of breastfeeding facilities and breast milk corners, the high percentage of complete basic immunizations for children, the low prevalence of malnutrition in children under five, low infant mortality rate (IMR), and the achievement and achievement of PIKKRR (Adolescent Reproductive Health Counseling Information Center) as reproductive and mental health institutions for children in South Tangerang City. Nevertheless, the fulfillment of children's rights is not yet fully optimal because it is more due to the following things.

First, Policy Size and Purpose. The purpose of the Regional Work Unit Development Policy in South Tangerang City is in accordance with what is stated in the Minister of Women's Empowerment and Child Protection Regulation No. 11 of 2011 concerning Development Policies for Decent Cities / Children, to build district / city government initiatives that lead to efforts to transform the Convention on the Rights of the Child from the legal framework into definitions, strategies and development interventions, in the form of: development policies, programs and activities aimed at the fulfillment of children's rights, in a district / city area. Then it can be said that the process of the size and purpose of the Regional Work Unit Development Policy in South Tangerang City has gone well. Second, resources consist of human resources, financial resources, and time resources. Human resources in the implementation of development policies in South Tangerang City are sufficient in quality and quantity. Financial resources come from the Regional Revenue Budget, which is sufficient for the implementation of the Eligible City of Children development policy, but it is still considered limited or has not fully met the needs for socialization activities and also for the development of children's rights cluster facilities and infrastructure. And for time resources, the South Tangerang City Government's own policy does not have a clear time target because the policy must be sustainable.

\section{Recommendations}

Based on the results of research from this writing, the recommendations are as follows: (1) Improving synchronization by equating the view of the urgency of fulfilling children's rights for SKPD; (2) Conduct more incentive communication between Child Friendly City Task Force and periodic monitoring so that the implementation of Eligible City of Children Development Policy in South Tangerang City is more optimal. Also by following up on every decision on the results of the coordination meeting; (3) Developing shelter houses by the South Tangerang City Government so that the local government can provide guidance and rehabilitation for street children. As well as by conducting a more even socialization, because no matter how good the Eligible City of Children Development program or activity should have been echoed as much as possible so that it can be felt by children and the community, so that community awareness and active role can also be improved. The socialization and strengthening of the Child Protection Task Force (Task Force PA) at the RW level also needs to be done so that they can play an active role in preventing child abuse and can be recognized by the community's roles and functions.

\section{REFERENCES}

Abidin, Said Zainal, (2012). Public Policy. Jakarta: Sakemba Humanika.

Agustino, Leo, (2008. Basics of Public Policy. Bandung: CV Alfabeta.

Dunn, William N. 2003. Introduction to Public Policy Analysis Second Edition. Yogyakarta: Gadjah Mada University Press.

Nugroho D. Riant, 2003. Public Policy: Implementation and Evaluation Formulations. Jakarta: PT Elex Media Komputindo.

Parson, W. 2005. Public Policy: An introduction to the theory and practice of policy analysis. Jakarta: Prenada Media.

Subarsono. 2006. Public Policy Analysis: Concepts, Theories, and Applications. Yogyakarta: Learning Library.

Wahab, Abdul Solichin. 2005. Policy Analysis: from the formulation to the Implementation of State Policy. Jakarta: Bumi Aksara.

Wicaksono, Kristian Widya. 2006. Government Administration and Bureaucracy. Yogyakarta: Graha Ilmu.

Winarno, Budi. 2012. Public Policy, Theory and Process. Jakarta: Media Pressindo.

Law No.23 of 2002 concerning Child Protection

Regulation of the Minister of State for Women's Empowerment and Child Protection of the Republic 
of Indonesia Number 11 of 2011 concerning Development Policy for Decent Districts / Cities

Regulation of the Minister of State for Women Empowerment and Child Protection of the Republic of Indonesia Number 12 of 2011 concerning Indicators of Child Friendly Districts / Cities

Regulation of the Minister of State for Women Empowerment and Child Protection of the Republic of Indonesia Number 13 of 2011 concerning Guidelines for the Development of Decent Districts / Cities
Regulation of the Minister of State for Women Empowerment and Child Protection of the Republic of Indonesia Number 14 of 2011 concerning Evaluation Guidelines for Decent Cities / Children

South Tangerang City Regional Regulation Number 3 of 2012 concerning Protection of Women and Children Victims of Violence. 